\title{
Response to thyrotrophin-releasing hormone in atrial dysrhythmias
}

\author{
C. SymONS \\ M.D., F.R.C.P. \\ D. KingSTONE \\ H.N.C.
}

\author{
A. MYERS \\ M.B., M.R.C.P. \\ M. Boss \\ B.Sc.
}

Departments of Cardiology and Endocrinology, The Royal Free Hospital, London NW3 2QG

\begin{abstract}
Summary
Seventy-eight clinically euthyroid patients with atrial dysrhythmias, either established or paroxysmal, and sixty-three patients in sinus rhythm with coronary disease were screened for hyperthyroidism using thyroid function tests including the thyroid-stimulating hormone (TSH) response to thyrotrophin-releasing hormone (TRH). All had normal levels of serum thyroxine (T4) apart from three with dysrhythmias who were found to have hyperthyroidism. Twenty per cent of patients with atrial dysrhythmias and $10 \%$ of those in sinus rhythm had exaggerated TSH response to TRH. Thirty-six per cent of patients with an exaggerated response of TSH to TRH had significant titres of thyroid auto-antibodies compared with $15 \%$ with positive antibodies in those with normal TSH response to TRH. Auto-immune thyroid disease may be more closely related to heart disease than has previously been recognized. Rapid atrial dysrhythmias may occur in the presence of a normal serum thyroxine, high levels of TSH and positive thyroid antibodies.
\end{abstract}

\section{Introduction}

Thyrotoxicosis is a well recognized cause of atrial dysrhythmias but frequently the endocrine component may not be clinically evident (Symons, Richardson and Wood, 1971); thus, a remediable cause of cardiac disability may go unrecognized. The results are now reported of screening a group of euthyroid patients with cardiac disorder, using thyroid function tests including the thyroidstimulating hormone (TSH) response to thyrotrophin releasing hormone (TRH) (Ormston et al., 1971; Birk Lauridsen et al., 1974).

\section{Patients and methods}

Three groups of clinically euthyroid patients were studied over a period of approximately 2 years. The first group comprised fifty patients who were known to have had atrial fibrillation for at least one year before this study. There were fourteen with rheumatic heart disease, six with ischaemia due t⿳亠口冋丁. coronary artery disease and thirty with idiopathie atrial fibrillation. In those with idiopathic fibrife lation, although the dysrhythmia was probably due to some form of cardiac ischaemia, there was n\& symptomatic or electrocardiographic evidence of coronary disease. The second group of twenty-eight patients were known to have had at least one proved attack of atrial dysrhythmia (atrial fibrie lation, flutter or tachycardia); there were two wit? rheumatic heart disease, five with ischaemia due to coronary disease, and twenty-one with idiopathi $\vec{G}$ atrial fibrillation without evidence of coromar.\% artery disease. The third group of sixty-thee patients were in sinus rhythm without history:- of dysrhythmia (initially conceived as a control series. but who had long-standing coronary artery disease No one with acute cardiac ischaemia was studiec

TABle 1. Age and sex of patients in groups 1-3

\begin{tabular}{lcccc}
\hline Group & Male & Female & $\begin{array}{c}\text { Mean age } \\
\text { (years) }\end{array}$ & $\begin{array}{c}\text { Range } \\
\text { (yeargi }\end{array}$ \\
\hline 1 & $18(35 \%)$ & $32(65 \%)$ & 64 & $40-8 \%$ \\
2 & $14(50 \%)$ & $14(50 \%)$ & 60 & $24-8 \%$ \\
3 & $22(34 \%)$ & $41(66 \%)$ & 62 & $32-8 \%$ \\
\hline
\end{tabular}

Because of the preponderance of elderly females id the first two groups, after the first twenty in group three, male subjects were excluded. This resulted io groups one and three being age- and sex-matche (Table 1). Otherwise patients were unselectech being added to the series either as they attended out patient clinics or were admitted. Conventiona cardiac and general investigations were carried out as indicated (chest X-rays, electrocardiograms, echofu cardiograms). Those with a history of thyroigh disorder and any who had an enlarged thyroid gland were excluded. The following tests of thyroif function were carried out on each patient:

1. Serum thyroxine (T4) measured by radioimmunoassay (RAI) (mean T4 $=91 \mathrm{nmol} / \mathrm{l}$, norma range $58-128 \mathrm{nmol} / \mathrm{l})$. 
2. Serum TSH, measured by RIA before and after $200 \mu \mathrm{g}$ of TRH intravenously (normal range: basal level $\leqslant 5 \mu \mathrm{u} . / \mathrm{ml}, 20 \mathrm{~min} \leqslant 20 \mu \mathrm{u} . / \mathrm{ml}, 60 \mathrm{~min} \leqslant 15$ $\mu \mathrm{u} . / \mathrm{ml})$. For the purpose of this study patients have only been included as showing an exaggerated response (i.e. abnormal responder) when the level at $20 \mathrm{~min}$ was $30 \mu \mathrm{u} . / \mathrm{ml}$ or more (Gordin et al., 1974; Gordin and Lamberg, 1975).

3. In patients with abnormal TSH/TRH results, both thyroglobulin and microsomal antibody titres were measured by haemagglutination techniques (Bird and Stephenson, 1973; Perrin and Bubel, 1974). They were also measured in a representative number (ninety-six cases) of other patients from all groups with normal TSH/TRH tests. Titres in excess of $1: 1000$ were considered significant for microsomal antibodies and $1: 100$ for thyroglobulin antibodies.

4. Serum cholesterol levels (normal 3.5-6.5 $\mathrm{mmol} / \mathrm{l})$.

\section{Results}

The TSH/TRH test and antibody results are shown in Table 2 and T4 levels in Table 3.

TABLE 2. Number of abnormal TSH/TRH tests and positive thyroid auto-antibody titres

\begin{tabular}{lcccc}
\hline & $\begin{array}{c}\text { Total } \\
\text { no. of } \\
\text { patients }\end{array}$ & $\begin{array}{c}\text { Abnormal } \\
\text { TSH/TRH } \\
\text { responders }\end{array}$ & $\begin{array}{c}\text { Positive } \\
\text { antibodies } \\
\text { in abnormal } \\
\text { responders }\end{array}$ & $\begin{array}{c}\text { Positive } \\
\text { antibodies } \\
\text { in normal } \\
\text { responders }\end{array}$ \\
\hline 1 & 50 & $12(24 \%)$ & $4 / 12(33 \%)$ & $5 / 38(13 \%)$ \\
2 & 28 & $4(14 \%)$ & $1 / 4(25 \%)$ & $3 / 20(15 \% *)$ \\
3 & 63 & $6(10 \%)$ & $3 / 6(50 \%)$ & $6 / 38(16 \% \dagger)$ \\
\hline
\end{tabular}

* Including one patient who had only positive thyroglobulin antibodies.

† Including two patients who had only positive thyroglobulin antibodies.

TABle 3. Serum T4 levels (nmol/l) of all patients

\begin{tabular}{|c|c|c|}
\hline Group & $\begin{array}{c}\text { Mean T4 } \pm \text { s.d. } \\
\text { for normal } \\
\text { TSH/TRH responders }\end{array}$ & $\begin{array}{c}\text { Mean T4 } \pm \text { s.d. } \\
\text { for abnormal } \\
\text { TSH/TRH responders }\end{array}$ \\
\hline $\begin{array}{l}1 \\
2 \\
3\end{array}$ & $\begin{array}{r}88 \pm 17 \\
89 \pm 21 \\
101 \pm 17\end{array}$ & $\begin{array}{l}74 \pm 17 \\
87 \pm 23 \\
89 \pm 14\end{array}$ \\
\hline
\end{tabular}

In group 1, forty-one patients including four abnormal responders had basal TSH levels of $\leqslant 5 \mu \mathrm{u}$. $/ \mathrm{ml}$; of the nine patients who had basal TSH levels of $>5 \mu \mathrm{u} . / \mathrm{ml}$, eight were abnormal responders. Four of the patients with abnormal TRH tests had positive antibodies. All the abnormal responders were female. Two were found to be hyperthyroid (TSH levels $<1.0 \mu \mathrm{u}$./ml basally, 20 and $60 \mathrm{~min}$ after TRH, serum T4 $>200 \mathrm{nmol} / \mathrm{l}$, thyroid antibodies positive in both cases).
In group 2, twenty-five patients including one abnormal responder had basal TSH levels $\leqslant 5$ $\mu \mathrm{u} . / \mathrm{ml}$; three patients, all of whom were abnormal responders, had basal TSH levels $>5 \mu \mathrm{u} . / \mathrm{ml}$. One of the four abnormal responders had positive antibodies. All the abnormal responders were female. One patient was found to be hyperthyroid; TSH levels were $1.0 \mu \mathrm{u}$./ml basally, 20 and $60 \mathrm{~min}$ after TRH, serum thyroxine $>200 \mathrm{nmol} / \mathrm{l}$ and thyroid antibodies positive.

In group 3, fifty-eight patients including two abnormal responders had basal TSH levels $\leqslant 5.0$ $\mu \mathrm{u} . / \mathrm{ml}$; five patients, including four abnormal responders had basal TSH levels $>5.0 \mu \mathrm{u} . / \mathrm{ml}$. Of the abnormal responders one was male and three had positive antibodies. Thirty-six per cent of those with an exaggerated response of TSH to TRH $(31 \%$ with atrial dysrhythmias and $50 \%$ with sinus rhythm) had significant titres of thyroid auto-antibodies compared to $15 \%$ with positive antibodies in those with normal TSH response to TRH.

The serum cholesterol levels did not differ significantly in any group nor did they differ between normal and abnormal responders to TRH (Table 4).

TABLE 4. Scrum cholesterol levels $\mathrm{mmol} / \mathrm{l}$ of all patients

\begin{tabular}{lcc}
\hline Group & $\begin{array}{c}\text { Mean cholesterol } \pm \text { s.d. } \\
\text { for normal } \\
\text { TSH/TRH responders }\end{array}$ & $\begin{array}{c}\text { Mean cholesterol } \pm \text { s.d. } \\
\text { for abnormal } \\
\text { TSH/TRH responders }\end{array}$ \\
\hline 1 & $6 \cdot 1 \pm 2 \cdot 8$ & $5 \cdot 7 \pm 1 \cdot 2$ \\
2 & $6 \cdot 1 \pm 0.85$ & $7 \cdot 3 \pm 0 \cdot 7$ \\
3 & $5 \cdot 7 \pm 1 \cdot 3$ & $6 \cdot 3 \pm 0.9$ \\
\hline
\end{tabular}

No significant difference between the groups (Student's $t$ test).

\section{Discussion}

In this study the initial purpose was to detect patients with occult thyrotoxicosis, especially in those with atrial dysrhythmias, and three were found, two with established and one with paroxysmal atrial fibrillation. Each had a raised T4 and a TSH/TRH test would not normally have been required to detect these cases. This suggests that a serum T4 estimation is a useful routine investigation in any patient with atrial dysrhythmia, for approximately $5 \%$ will have unsuspected thyrotoxicosis. No subjects with hypothyroidism were discovered. The unexpected feature of these results was the high incidence of an exaggerated TSH response to TRH in all three groups, in the presence of a normal serum $\mathrm{T} 4 ; 24 \%$ of the atrial fibrillation group, $14 \%$ of the paroxysmal group and $10 \%$ of those with ischaemic heart disease in sinus rhythm had abnormal TSH/ TRH tests, i.e. $16 \%$ of clinically euthyroid patients with heart disease were found to have this biochemical finding. The higher proportion with an 
exaggerated response in the atrial dysrhythmia groups compared with those in sinus rhythm is of interest but is significant only at the $5 \%$ level. It had originally been thought that the patients in sinus rhythm would have acted as a control group in contrast to those with dysrhythmia but it soon became apparent that an abnormal TRH response was common in both types of patient. The response was not associated with any particular drug or combination of drugs, for a wide spectrum of medication has been employed in these cardiac patients and none can be regularly related to the abnormalities reported here. The mean T4 level of the abnormal responders in the atrial fibrillation groups is slightly lower, although within normal limits, than the mean T4 level of the normal responders in sinus rhythm.

Several reports have been published of euthyroid patients who have abnormal TSH/TRH tests, notably those who have had thyroidectomies (Hedley et al., 1971; Bellabarba, Benard and Langlois, 1972) treatment with 131I (Tunbridge, Harsoults and Goolden, 1974; Toft et al., 1974) auto-immune thyroiditis (Gordin et al., 1974; Gordin and Lamberg, 1975) exophthalmos (Chopra et al., 1974; Franco et al., 1973) and malnutrition (Pimstone, Becker and Hendricks, 1973). The reason for the raised TSH levels in these cases is unknown but it has been suggested that excessive pituitary drive on the normal remaining thyroid gland is required to maintain an euthyroid status (Tunbridge et al., 1974). The authors have been unable to find any reported study of the frequency of occurrence of abnormal TSH/TRH tests in normal or euthyroid subjects. The only value for TSH in a general population is a basal figure reported by the Whickham Survey Group where $2.8 \%$ of males and $7.5 \%$ of females had TSH levels of greater than 6 $\mu \mathrm{u} . / \mathrm{ml}$ (Tunbridge, 1976). But a single TSH estimation is of limited use, because, of the abnormal responders in the present report, seven had initial levels of less than $6.0 \mu \mathrm{u} . / \mathrm{ml}$, i.e. the complete TSH/ TRH test must be employed if its full value is to be realized, and this is also the view of AlaghbandZadeh et al. (1977). The percentage of patients with positive thyroid antibodies in the three groups (20, 28, 18\% respectively), albeit in a hospital population, is also higher than expected. In a mixed hospital and volunteer group of middle-aged women, Mittra, Perrin and Kumaoka (1976) found antibodies in $26 \%$, but their lower limits of titres were less than the present series, namely $1: 20$ for thyroglobulin and $1: 100$ for microsomal antibodies. In contrast, the Whickham Survey found that in a general population microsomal antibodies were present in 2.7 males and $\mathbf{1 0 . 3} \%$ females with lower figures for thyroglobulin antibodies (Tunbridge, 1976;
Tunbridge et al., 1976). Over a third of the presen cases who responded abnormally to TRH had positive antibodies. The difference between the proportion of abnormal TSH/TRH responders and? normal responders who have positive antibodieso shown in Table 2, suggests that the abnormally responding patients have some form of thyroief auto-immune disease, although the numbers fo $\mathbb{2}$ comparison are too small to be significant.

Of the twelve patients who had atrial dysrhythmias and an exaggerated TRH response, three presented with fast atrial fibrillation more in keeping with hyperthyroidism than depressed thyroid reserve op hypothyroidism (where in any case atrial fibrillatiof is an unusual finding). In the majority of patients, the ventricular response was adequately controlled by digoxin, occasionally with propranolol, but in twB cases this had only minimal effect and carbimazoles was given. There was no improvement and the serunis TSH increased. A cautious trial of triiodothyronineo was instituted with little clinical response but the serum TSH fell to the lowest level of normal, thusdemonstrating the integrity of the hypothalamice pituitary axis. The duration of the ankle tendore reflex was not prolonged in any of the twenty-twe patients who responded abnormally to TRH. It was. not possible to differentiate clinically betwe patients with an abnormal or normal TSH/THF response. To date, follow-up observation of abnormal TRH responders has not disclosed anyह progression to obvious hypothyroidism.

A normal serum thyroxine, raised TSH levels an positive thyroid antibodies is suggestive of preळ clinical hypothyroidism or low thyroid reserve Although the latter may account for the abnormas findings it does not explain why in many instances the presentation with tachycardia and atrial fibril: lation should be so unlike the picture of thyroid insufficiency, or why the number of cardiac patients with abnormal tests should be so high. Bastenie Vanhaelst and Neve (1967) and Fowler, Swale and Andrews (1970) have suggested an association between thyroid and ischaemic heart disease an 9 Tunbridge et al. (1976) have hinted of this in females The present data do not entirely support this view for although the authors found a high incidence of abnormal TSH/TRH tests in the ischaemic group. owing to coronary artery disease, the percentage of patients with abnormal TSH/TRH tests was greater in the dysrhythmia groups where ischaemia froni coronary disease was less prevalent. Also, the serung cholesterol levels did not differ in any of the groups? Atrial muscle disease has been reported in thyrof toxicosis (Wan, Lee and Toh, 1972) and Fairfax an Leatham (1975) have described patients with idiopathic heart block who had thyroid or othes auto-immune disorders. As has been suggested $b{ }^{\circ}$ 
Mathews, Whittingham and Mackay (1974), the auto-immune process itself may be invoked as a cause of vascular disease and the action on the cardiovascular system of circulating immune complexes in thyroid disease and even of the metabolic effects of high concentration of TSH needs to be explored (Bastenie et al., 1977). The present authors suggest that the problem is much wider than that of a correlation simply between symptomless autoimmune thyroiditis and coronary disease and that other types of heart disease especially with atrial dysrhythmia may be produced or aggravated by auto-immune processes.

The authors cannot explain why a high proportion of their patients have positive thyroid antibodies but there is a hypothesis which can account for their other findings. Thyroid auto-immune disease, present in a large number of their cases, might result in the abnormal breakdown of thyroxine with the formation of analogues of thyroxine (Braverman, Ingbar and Sterling, 1970), namely triac or tetrac. This would explain the euthyroid state (for these compounds have a weak metabolic action [Lerman and Pitt-Rivers, 1956]), the partial suppression of thyroid activity with a consequent rise in TSH and also a specific effect on the heart. Triac has a specific and profound action on heart muscle in that experimentally it increases cardiac cellular oxygen requirements (Barker and Lewis, 1956) and alters fibre morphology (Symons, Olsen and Hawkey, 1975; Olsen, Symons and Hawkey, 1977). The presence of triac and tetrac in the serum of a patient with thyrocardiac disorder has been reported previously (Symons, Richardson and Wood, 1971) and the measurement of circulating analogues of thyroxine in patients with auto-immune thyroid disease and cardiac disorders is required.

\section{Acknowledgment}

We thank the National Pituitary Agency, Bethesda, for supplies of human TSH for iodination and rabbit anti-human TSH serum, also Dr D. R. Bangham for the Medical Research Council LTSH fraction 68/38 which was used as standard, and Mr R. L. Markham for assistance with antibody studies.

\section{References}

Alaghband-Zadeh, J., Carter, G.D., Daly, J.R., Fowler, P.B.S. \& GREENWOOD, T.W. (1977) Association between exaggerated responsiveness to thyrotrophin-releasing hormone and hypercholesterolaemia. Lancet, ii, 998.

BARKer, S.B. \& LEWIS, W.J. (1956) Metabolic actions of acetic acid analogs of thyroxine and triiodothyronine. Proceedings of the Society for Experimental Biology and Medicine, 91, 650.

Bastenie, P.A., Golstein, J., Vanhaelst, L., Smets, Ph., Keys, A., Karvonen, M.J. \& Punsar, S. (1977) Asymptomatic autoimmune thyroiditis in coronary heart-disease. Lancet, ii, 155.

Bastenie, P.A., Vanhaelst, L. \& Neve, P. (1967) Coronaryartery disease in hypothyroidism. Lancet, ii, 1221.
Bellabarba, D., Benard, B. \& Langlois, M. (1972) Pattern of serum thyroxine, triiodothyronine and thyrotrophin after treatment of thyrotoxicosis. Clinical Endocrinology, 1, 345.

Bird, T. \& Stephenson, J. (1973) Evaluation of a tanned red cell technique for thyroid microsomal antibodies. Journal of Clinical Pathology, 26, 623.

Birk Lauridsen, U., Deckert, T., Fris, Th., Kirgaard, C., Møholm Hansen, J. \& Siersbaek-Nielsen, K. (1974) Estimation of serum thyrotropin (TSH) and stimulation with thyrotropin-releasing hormone (TRH) in thyroid diseases. Acta medica scandinavica, 196, 171.

Braverman, L.E., Ingbar, S.H. \& Sterling, K. (1970) Conversion of thyroxine (T4) to triiodothyronine (T3) in athyreotic human subjects. Journal of Clinical Investigation, 49, 855 .

Chopra, I.J., Chopra, U., VanderlaAn, W.P. \& Solomon, D.H. (1974) Comparison of serum prolactin and thyrotropin responses to thyrotropin-releasing hormone in patients with Graves' ophthalmopathy. Journal of Clinical Endocrinology and Metabolism, 38, 683.

FairfaX, A.J. \& Leatham, A. (1975) Idiopathic heart block: association with vitiligo, thyroid disease, pernicious anaemia and diabetes mellitus. British Medical Journal, 4, 322.

Fowler, P.B.S., Swale, J. \& Andrews, H. (1970) Hypercholesterolaemia in borderline hypothyroidism. Lancet, ii, 488.

Franco, P.S., Hershman, J.M., Haigler, E.D. \& Pittman, J.A. (1973) Response to thyrotropin-releasing hormone compared with thyroid suppression tests in euthyroid Graves' disease. Metabolism, 22, 1357-1365.

Gordin, A. \& LAMBERG, B-A. (1975) Natural course of symptomless auto-immune thyroiditis. Lancet, ii, 1234.

Gordin, A., SaArinen, P., Pelkonen, R. \& Lamberg, B-A. (1974) Serum thyrotrophin and the response to thyrotrophin releasing hormone in symptomless autoimmune thyroiditis and in borderline and overt hypothyroidism. Acta endocrinologica. Copenhagen, 75, 274.

Hedley, A.J., Amos, J., Hall, R., Michie, W. \& Crooks, J. (1971) Serum-thyrotrophin levels after subtotal thyroidectomy for Graves' disease. Lancet, i, 455.

Lerman, J. \& Pitr-Rivers, R. (1956) Physiologic activity of triiodo and tetraiodothyroacetic acid in human myxoedema. Journal of Clinical Endocrinology and Metabolism, 16, 1470.

Mathews, J.D., Whittingham, S. \& MaCKay, I.R. (1974) Autoimmune mechanisms in human vascular disease. Lancet, ii, 1423.

Mittra, I., Perrin, J. \& Kumaoka, S. (1976) Thyroid and other autoantibodies in British and Japanese women: an epidemiological study of breast cancer. British Medical Journal, 1, 257.

Olsen, E.G.J., Symons, C. \& HaWkey, C.M. (1977) Effects of triac on the developing heart, Lancet, ii, 221.

Ormston, B.J., Cryer, R.J., Garry, R., Besser, G.M. \& HaLl, R. (1971) Thyrotrophin-releasing hormone as a thyroid-function test. Lancet, ii, 10.

Perrin, J. \& Bubel, M.A. (1974) Assessment of a haemagglutination test for thyroid microsomal antibody. Medical Laboratory Technology, 31, 205.

Pimstone, B., Becker, D. \& Hendricks, S. (1973) TSH response to synthetic thyrotropin-releasing hormone in human protein-calorie malnutrition. Journal of Clinical Endocrinology and Metabolism, 36, 779.

Symons, C., Olsen, E.G.J. \& Hawkey, C.M. (1975) The production of cardiac hypertrophy by tri-iodothyroacetic acid. Journal of Endocrinology, 65, 341.

Symons, C., Richardson, P.J. \& Wood, J.B. (1971) Uuusual presentation of thyrocardiac disease. Lancet, ii, 1163. 
Toft, A.D., Irvine, W.J., Hunter, W.M. \& Seth, J. (1974) Plasma TSH and serum T-4 levels in long-term follow-up of patients treated with ${ }^{13} \mathrm{I}$ for thyrotoxicosis. British Medical Journal, 3, 152.

Tunbridge, W.M.G. (1976) Personal Communication.

Tunbridge, W.M.G., Evered, D.G., Hall, R., Appleton, D., Brewis, M., Clark, F., Grimley-Evans, J., Young, E., BIRD, T. \& SMITH, P. (1976) The prevalence of thyroid disorders in an English community. Proceedings of the 7th International Thyroid Conference, Boston, Mass $\$$ June 1975, In: Excerpta Medica, I.C.S., 378, 520.

Tunbridge, W.M.G., Harsoulis, P. \& Goolden, A.W.G. (1974) Thyroid function in patients treated with radio active iodine for thyrotoxicosis. British Medical Journal, $\underset{\vec{f}}{\vec{q}}$ 89.

WAN, S.H., LeE, G.S. \& ToH, C.C.S. (1972) The sick sinus̀ syndrome, a study of 15 cases. British Heart Journal, 34, 942. 